Article

\title{
Teacher Recruitment: Factors That Predict High School Students' Willingness to Become Teachers
}

\author{
Steven S. Christensen, Randall S. Davies * ${ }^{\mathbb{D}}$, Scott P. Harris, Joseph Hanks and Bryan Bowles \\ Instructional Psychology \& Technology Department, McKay School of Education, Brigham Young University, \\ Provo, UT 84602, USA; Steven.Christensen@byu.edu (S.S.C.); Scott.Harris@byu.edu (S.P.H.); \\ JosephHanks@gmail.com (J.H.); bryan.bowles@byu.edu (B.B.) \\ * Correspondence: Randy.Davies@byu.edu
}

Received: 31 October 2019; Accepted: 26 November 2019; Published: 28 November 2019

check for updates

\begin{abstract}
This study examines factors that influence high school students' willingness to consider teaching as a career. Using predictive modeling, we identified five factors that are highly predictive of a students' willingness to consider teaching and their belief that teaching is their best career option. Results indicated that high school students were more likely to consider teaching when they had confidence in their ability to be good teachers, when family members and others encouraged them to become teachers, and when they felt their community supported teachers. Most of those who considered teaching thought of themselves as average students. Less impactful factors included gender and pay. Additionally, this study found students less likely to consider work conditions for teachers when making career choices.
\end{abstract}

Keywords: teacher education; teacher recruitment; teacher profession; teacher shortage; perceptions on the teaching profession; career choice; high school students; self-efficacy

\section{Introduction}

For some time now, schools in the United States, and other places in the world, have struggled to keep teachers in classrooms [1]. Various attrition estimates suggest that $20 \%$ to $50 \%$ of new teachers in the United States leave the profession within their first five years of service; with approximately $10 \%$ of all teachers leaving the profession each year [2-4]. Currently, few teachers stay in the profession until retirement [5]. Complicating the issue is the fact that student enrollments continue to increase and the number of individuals entering the teaching profession has decreased [6] As a result, many researchers anticipate that the teacher shortage in the United States will continue for some time [7,8].

Of the conditions contributing to the current teacher shortage in the United States, perhaps the most alarming is the decrease in the number of individuals entering teacher education programs across the country [6,9]. Over the last decade, fewer high school graduates have shown interest in pursuing a teaching education major in college. In 2010, $15 \%$ of high school students indicated they might be interested in pursuing a career in teaching, falling to 12\% in 2014 [10]. Nationwide, U.S. teacher preparation programs have experienced a 35\% decrease in enrollments from 2009 to 2014, while overall university enrollments have declined only $3 \%$, and students are increasingly choosing other careers over teaching $[9,11]$. As the demand for teachers steadily increases, the supply of qualified teachers has decreased, making the typical solution to attrition - recruiting and hiring of new teachers-less likely to succeed [12].

\section{Research Purpose and Questions}

To better understand the teacher recruitment problem, this study asked which factors best predicted whether high school students would consider teaching as a career and whether they felt 
teaching was their best career choice. This study was a part of a larger teacher retention and recruitment study conducted with students, teachers, school administrators, and parents in a sampling of school districts in one state. The study was designed to examine factors identified from previous research that affect teacher recruitment. Two research questions were addressed: (a) Which factors predict whether high school students are willing to consider teaching as a career? (b) Which factors predict whether high school students feel teaching is the best career option for them? Both these questions are important because, as many researchers have found, potential teachers might be willing to consider teaching as a career, but do not feel teaching is the best career option for them.

\section{Review of Factors Influencing Teacher Recruitment Literature}

A plethora of researchers have studied why teachers leave the profession; however, less is known about why people originally choose not to go into teaching [13]. The studies that do examine teacher recruitment typically focus on pre-service teachers' reflections of why they chose to teach, but not on individuals (high school students and others) who do not consider teaching as a viable career. While expectancy theory [14] and social cognitive career theory [15] provide a basis for the understanding that career choice is complicated by a variety of factors, interests, and contexts, most research attempts to identify factors that individuals consider when making career choices, but not to determine which of these factors are most influential in their final choice.

In general, research studies suggest that teaching has traditionally been considered a respected profession, particularly a suitable job for women. Yet increasingly teachers are not held in such high regard $[16,17]$. Studies have shown that those entering the teaching profession have not been the most academically motivated or accomplished students [3,17]. Research has also shown that pay and work conditions have been identified as factors that dissuade individuals from becoming teachers [18]. Many of those choosing to teach have been able to overlook some negative aspects like low pay and difficult work conditions because they considered teaching to be a calling, citing altruistic or social utility motivations $[16,19]$. Factors that researchers have identified as impacting whether or not an individual will enter the teaching profession are presented in Table 1 . These were used in the development of the data collection instruments used in this study.

Table 1. General factors included in this analysis believed to influence teacher recruitment.

\begin{tabular}{cc}
\hline Factor & Sources \\
\hline Gender & {$[20,21]$} \\
Altruistic motivations & {$[17,19]$} \\
Work conditions for teachers & {$[18]$} \\
Respect for teachers \& profession & {$[20,21]$} \\
Self-efficacy \& personal interests & {$[22]$} \\
School success & {$[17]$} \\
Encouragement from others & {$[23]$} \\
Teacher's lifestyle & {$[21]$} \\
Teacher compensation & {$[18]$}
\end{tabular}

Note: Multiple sources and consideration of aspects can be found for each general factor.

\section{Methodology}

In this study, we surveyed high school students to determine their perception of the teaching profession, then used a regression analysis to identify those factors that best predicted (a) whether students were considering teaching as a career and (b) whether they felt teaching was the best career option for them. These two dependent variables were analyzed separately using a univariate regression analysis. Factors measured through items on the survey were used as independent variables in each regression analysis. 


\subsection{Participants}

Juniors and seniors at 41 school districts across Utah were selected to participate in this study. Respectful of institutional review board (IRB) concerns for conducting research with minors, and considering the political concerns of the school districts involved, we were not surprised that of the 41 school districts, only nine agreed to allow us to send anonymous survey invitations through the district's email system to the junior and senior students within their care. Several school districts did allow us to survey administrators and teachers, but not parents and students. Of the nine districts that consented to have their students and parents surveyed, the smallest enrolls approximately 160 juniors and seniors at two high schools. The largest district enrolls approximately 7870 juniors and seniors at five high schools. The nine participating districts included both rural and urban settings across Utah, providing diverse coverage of the state. After removing incomplete surveys from the 285 student respondents, we found there were 264 (93\%) participants who fully completed the survey, of which $189(72 \%)$ were females. Those who did not complete had very sparse data and non-answers appear to be random, thus we felt justified in using listwise deletion on the data and only including those who had complete data.

While the response rates might be considered low, existing research involving high school students has been conducted with smaller response groups due to IRB restrictions, parental consent issues, and students' willingness to participate [24-26]. Krejecie and Morgan [27] suggested that a sample size similar to the one we obtained can be statistically representative for populations of 6,000 or more. The sample is of sufficient size for the statistical analysis, and we consider the results useful in understanding the teacher shortage in the state.

\subsection{Instrument Development and Distribution}

The instruments used for data collection were validated through a process recommended by [28]. Based on a review of literature that identified potentially important factors that might affect an individual's decision to choose teaching as a career, draft items were created. These items were tested and revised based on a cognitive think aloud process then pilot testing to verify that item did in fact capture the essence of the factors of interest. For example, the items that address respondents beliefs about their teaching ability (self-efficacy) were tested to verify that the items address the issue of self-efficacy and not just self-concept (how they felt about their perceived ability to be a teacher). Once the items were set, they were entered into an online survey software program to be distributed by cooperating school districts. In the spring of 2018, invitations to complete an anonymous online questionnaire were sent to all the juniors and seniors in the nine participating school districts by district personnel using their email system. For disaggregation purposes, the typical 6-point Likert scale was collapsed to three categories for reporting the results in this paper, although the full scale was used for the analysis.

\subsection{Data Analysis}

In order to answer the research questions concerning (a) the factors that predict whether a high school student would consider teaching as a profession, and (b) the factors that predict students' belief that there is a better profession than teaching for them, statistical analysis was done. This involved descriptive statistics as well as univariate analyses. The independent variables used for this analysis related to items regarding students' perceptions of a teaching career and their personal experiences. The assumptions for multiple regression are (a) linearity, (b) independence of observations, (c) normality of residuals, (c) equality of variance, and (d) multicollinearity. They are checked via (a) residual plots, (b) histograms of residuals, (c) variance inflation factors (VIFs), and (d) examining the structure of the data for independence. All statistical assumptions were met. 


\section{Results and Discussion}

Of the responses collected, only 59 students (22\%) agreed or strongly agreed that they would consider teaching as a career-higher than Aragon's estimate of $12 \%$ see [10]. However, only $4 \%$ of students in this study indicated they felt teaching was their best career option, and of these students, only $64 \%$ also indicated they would consider teaching as a career ( $3 \%$ overall). Therefore, while $57 \%$ of all responding students indicated that they might consider teaching, very few also felt that teaching was the best career option for them (see Table 2).

Table 2. Students considering teaching vs. those perceiving it as the best career option for them.

\begin{tabular}{|c|c|c|c|}
\hline \multirow[b]{2}{*}{ Teaching Is the Best Career Option for Me } & \multicolumn{3}{|c|}{ I Would Consider Teaching } \\
\hline & Disagree & Somewhat Agree & Agree \\
\hline Agreed (4\% of all respondents) & $18 \%$ & $18 \%$ & $64 \%$ \\
\hline Maybe $(27 \%)$ & $8 \%$ & $39 \%$ & $53 \%$ \\
\hline Disagreed $(69 \%)$ & $57 \%$ & $35 \%$ & $8 \%$ \\
\hline All Respondents & $43 \%$ & $35 \%$ & $22 \%$ \\
\hline
\end{tabular}

Note: Response distributions statistically different: $\chi^{2}(10)=88.3, p<0.001$.

\subsection{Students' Perception of Teaching}

Table 3 lists students' beliefs about teaching and indicates relative importance of those beliefs in their willingness to consider teaching as a career. The table presents two separate but related perceptions - the beliefs about each specific factor as well as the importance participants place on each factor.

Table 3. Students' beliefs about teaching and the importance of these individual factors to students in considering teaching as a career.

\begin{tabular}{|c|c|c|c|c|}
\hline Beliefs about Teaching & Disagree & $\begin{array}{l}\text { Somewhat } \\
\text { Agree }\end{array}$ & Agree & $\begin{array}{l}\text { Important or Very } \\
\text { Important }\end{array}$ \\
\hline Teachers are paid well. & $61 \%$ & $36 \%$ & $3 \%$ & $83 \%$ \\
\hline Teacher have the resources they need to do their job. & $25 \%$ & $57 \%$ & $18 \%$ & $81 \%$ \\
\hline Work conditions for teachers are good. & $9 \%$ & $54 \%$ & $37 \%$ & $81 \%$ \\
\hline Teachers have a good lifestyle. & $8 \%$ & $47 \%$ & $45 \%$ & $76 \%$ \\
\hline Expectations of teachers are reasonable. & $15 \%$ & $46 \%$ & $39 \%$ & $75 \%$ \\
\hline Students are well behaved and care about learning. & $34 \%$ & $57 \%$ & $9 \%$ & $75 \%$ \\
\hline Teachers are well respected in the community. & $8 \%$ & $54 \%$ & $38 \%$ & $63 \%$ \\
\hline Most teachers I know are good teachers. & $10 \%$ & $45 \%$ & $45 \%$ & $62 \%$ \\
\hline You need to have a certain personality to be a teacher. & $7 \%$ & $35 \%$ & $58 \%$ & $59 \%$ \\
\hline People are very supportive of teachers. & $3 \%$ & $50 \%$ & $57 \%$ & $52 \%$ \\
\hline
\end{tabular}

In general, students' perceptions of the teaching profession were somewhat ambivalent. Just over half agreed that people support teachers, but only one-third felt teachers were well respected in the community. When asked about work conditions, students also tended to be somewhat neutral. Many felt that work conditions for teachers were important, but only one-third agreed that work conditions for teachers were good and expectations were reasonable. It was not too surprising to find that only $9 \%$ of respondents felt that students in school were well behaved and cared about learning.

Teacher salary was the factor that students (83\%) felt was most important in their decision to be a teacher; but only $3 \%$ felt teachers are paid adequately for the job they do. We were interested to find that $58 \%$ of respondents felt that being a good teacher requires a certain type of personality. Some might relate this to recognizing that not all have an aptitude for teaching. Still, students attributed greater importance to other factors, even though self-efficacy (the belief that one would be a good teacher) was the factor that most strongly predicted whether an individual would consider teaching as a career. 


\subsection{Factors Predicting Student Career Decisions for Teaching}

Using data representing students' perceptions of teaching and other factors that researchers have identified as important, we conducted a predictive regression analysis to determine which factors best predicted whether students were willing to consider teaching as a career and whether they felt teaching was the best career option for them. Table 4 provides a list of the factors that were found to predict students' willingness to consider teaching as a career. Table 5 lists the factors found to be predictive of students' belief that other career options would be better for them. Table 6 lists those factors found not to be highly predictive in either regression. Statistical significance as well as the beta value for the regression, along with a descriptive label representing the influence of each factor, were included in each table.

Table 4. Factors predictive of students considering teaching as a career.

\begin{tabular}{cccc}
\hline Factor or Perception & Significance & Beta & Influence \\
\hline Self-efficacy & $<0.001$ & 0.514 & High \\
Others encourage them to be a teacher & $<0.001$ & 0.202 & High \\
Family encourages them to teach & 0.009 & 0.142 & High \\
Academic success & 0.016 & -0.106 & High \\
Student's Gender & 0.036 & 0.093 & High \\
Belief that teaching is a respectable profession & 0.047 & 0.104 & High \\
\hline
\end{tabular}

Table 5. Factors predictive of students' belief that they had better career options than teaching.

\begin{tabular}{cccc}
\hline Factor or Perception & Significance & Beta & Influence \\
\hline Belief that people support teachers & 0.006 & 0.203 & High \\
Self-efficacy & 0.015 & -0.168 & High \\
Family encouragement to teach & 0.026 & -0.162 & High \\
Academic success & 0.037 & 0.123 & High \\
\hline
\end{tabular}

Table 6. Factors found not to be highly predictive in any of the regressions.

\begin{tabular}{cccc}
\hline Factor or Perception & Significance & Beta & Influence \\
\hline Teacher Salary & 0.096 & 0.084 & Low/None \\
A member of my family is a teacher. & 0.096 & 0.074 & Low/None \\
Teachers I know are good. & 0.256 & 0.056 & Low/None \\
Expectations of teachers are reasonable. & 0.375 & -0.055 & Low/None \\
Teachers need to have a teacher personality. & 0.450 & 0.033 & Low/None \\
Students are well behaved in the classroom. & 0.497 & 0.035 & Low/None \\
Teachers are well respected in the community. & 0.591 & -0.030 & Low/None \\
Teachers have the needed resources to do their jobs. & 0.658 & 0.023 & Low/None \\
I've been inspired by teachers. & 0.828 & 0.012 & Low/None \\
Teachers have a good lifestyle. & 0.930 & -0.005 & Low/None \\
Work conditions for teachers are good. & 0.985 & -0.001 & Low/None \\
\hline
\end{tabular}

Of note is the fact that pay and work conditions were not primary indicators. Self-efficacy (confidence for being a good teacher), academic history (average or slightly above average student), perceptions of community support for teachers, and the degree to which students felt they had been encouraged to consider teaching, among others, were found to be influential factors.

\subsection{Analysis of Highly Influential Factors Predicting Students' Decisions}

\subsubsection{Self-efficacy}

This factor was the most important factor students considered when deciding about teaching as a career. Students needed to believe that they would be good at teaching to both consider going into the 
profession and believing it to be their best option; $44 \%$ of participants felt they could be a good teacher; but only $4 \%$ felt teaching was the best career option for them.

Tables 7 and 8 present response distributions for the factor of self-efficacy disaggregated by respondents indicating whether they would considering becoming a teacher and whether they felt teaching was the best career option for them. Of those who said they definitely were not considering teaching as a career, $49 \%$ likely did so because they felt they would not be good at teaching. In contrast, $86 \%$ of those who said they were considering a teaching career reported that they felt they would do well in teaching. Yet, while positive self-efficacy is important, it is not sufficiently predictive by itself: $35 \%$ of those who did not think teaching was a good career option for them felt they would be good at teaching, and $18 \%$ percent of respondents who said teaching was their best career option did not think they would be good teachers.

Table 7. Disaggregation of students' belief that they would be good teachers by their willingness to considering teaching.

\begin{tabular}{|c|c|c|c|}
\hline \multirow[b]{2}{*}{ I Would Consider Teaching as a Career } & \multicolumn{3}{|c|}{ I Would be a Good Teacher } \\
\hline & \multirow{2}{*}{$\begin{array}{c}\text { Disagree } \\
0\end{array}$} & \multirow{2}{*}{$\begin{array}{c}\text { Somewhat } \\
14 \%\end{array}$} & \multirow{2}{*}{$\begin{array}{c}\text { Agree } \\
86 \%\end{array}$} \\
\hline (22\% of all respondents) & & & \\
\hline Maybe $(35 \%)$ & $4 \%$ & $40 \%$ & $56 \%$ \\
\hline Disagree $(43 \%)$ & $49 \%$ & $38 \%$ & $13 \%$ \\
\hline All respondents & $22 \%$ & $34 \%$ & $44 \%$ \\
\hline
\end{tabular}

Note: Response distributions statistically different: $\chi^{2}(10)=141.4, p<0.001$.

Table 8. Disaggregation of students' belief that they would be good teachers by their belief that teaching was their best career option.

\begin{tabular}{cccc}
\hline & \multicolumn{2}{c}{ I Would be a Good Teacher } \\
\cline { 2 - 4 } Teaching Is My Best Career Option & Disagree & Somewhat & Agree \\
\hline Agreed $\quad(4 \%$ of all respondents) & $18 \%$ & $9 \%$ & $73 \%$ \\
Maybe (27\%) & $6 \%$ & $31 \%$ & $63 \%$ \\
Disagree (69\%) & $29 \%$ & $36 \%$ & $35 \%$ \\
All Respondents & $22 \%$ & $34 \%$ & $44 \%$ \\
\hline
\end{tabular}

Note: Response distributions statistically different: $\chi^{2}(10)=32.9, p<0.001$.

\subsubsection{Encouragement from Others}

Another indicator of students' willingness to consider teaching and belief that teaching would be their best career option involves encouragement. Results from these factors are disaggregated by the dependent variables in Tables 9-12, indicating the importance of encouragement. Overall, $64 \%$ of those considering teaching agreed their family had encouraged them to do so, and $41 \%$ indicated that others had encouraged them. Of those who had not considered becoming a teacher, few had received encouragement to teach: Only $20 \%$ from family and 5\% from others. Similar results were found regarding the item about teaching as a best career option. Those who felt teaching was not a viable career option for them did not receive encouragement from family (39\%) or others (58\%); while those who felt teaching was a good career choice were more likely to agree they received encouragement from family (46\%) or others (27\%), as depicted in Tables 11 and 12 .

Of relevance to this analysis are the results from the parent portion of this study. Only $36 \%$ of the 495 parents surveyed indicated they would encourage their child to become a teacher, and just $25 \%$ of these parents felt teaching would be a good career option for their child. In addition, $45 \%$ of those parents who were or had been teachers said they would not encourage their child to consider becoming a teacher. 
Table 9. Disaggregation of students' family encouragement by willingness to considering teaching.

\begin{tabular}{|c|c|c|c|}
\hline \multirow[b]{2}{*}{ I Would Consider Teaching as a Career } & \multicolumn{3}{|c|}{ Encouragement from Family Members } \\
\hline & Disagree & Somewhat Agree & Agree \\
\hline Agreed $(22 \%$ of all respondents $)$ & $7 \%$ & $29 \%$ & $64 \%$ \\
\hline Maybe $(35 \%)$ & $24 \%$ & $40 \%$ & $36 \%$ \\
\hline Disagree $(43 \%)$ & $52 \%$ & $28 \%$ & $20 \%$ \\
\hline All respondents & $32 \%$ & $32 \%$ & $36 \%$ \\
\hline
\end{tabular}

Note: Response distributions were statistically different: $\chi^{2}(10)=67.2, p<0.001$.

Table 10. Disaggregation of students' others encouragement by their willingness to considering teaching.

\begin{tabular}{ccccc}
\hline \multirow{2}{*}{ I Would Consider Teaching as a Career } & \multicolumn{2}{c}{ Encouragement from Those outside Family } \\
\cline { 2 - 4 } Agreed & Disagree & Somewhat Agree & Agree \\
\hline Maybe $\quad(35 \%)$ & $10 \%$ & $49 \%$ & $41 \%$ \\
Disagree (43\%) & $34 \%$ & $49 \%$ & $17 \%$ \\
All respondents & $73 \%$ & $22 \%$ & $5 \%$ \\
\end{tabular}

Note. Response distributions were not statistically different: $\chi^{2}(10)=88.4, p<0.001$.

Table 11. Disaggregation of students' family encouragement by their belief that teaching was their best career option.

\begin{tabular}{|c|c|c|c|}
\hline \multirow[b]{2}{*}{ Teaching Is My Best Career Option } & \multicolumn{3}{|c|}{ Encouragement from Family Members } \\
\hline & Disagree & Somewhat Agree & Agree \\
\hline Agreed $\quad(22 \%$ of all respondents) & $36 \%$ & $18 \%$ & $46 \%$ \\
\hline Maybe $(35 \%)$ & $14 \%$ & $27 \%$ & $59 \%$ \\
\hline Disagree $(43 \%)$ & $39 \%$ & $35 \%$ & $25 \%$ \\
\hline All respondents & $32 \%$ & $32 \%$ & $36 \%$ \\
\hline
\end{tabular}

Note. Response distributions statistically different: $\chi^{2}(10)=38.3, p<0.001$.

Table 12. Disaggregation of students' others encouragement by their belief that teaching was their best career option.

\begin{tabular}{cccc}
\hline & \multicolumn{2}{c}{ Encouragement from Others } \\
\cline { 2 - 4 } Teaching Is My Best Career Option & Disagree & Somewhat Agree & Agree \\
\hline Agreed $\quad(4 \%$ of all respondents) & $37 \%$ & $36 \%$ & $27 \%$ \\
Maybe (27\%) & $15 \%$ & $57 \%$ & $28 \%$ \\
Disagree (69\%) & $58 \%$ & $30 \%$ & $12 \%$ \\
All respondents & $46 \%$ & $37 \%$ & $17 \%$ \\
\hline
\end{tabular}

Note. Response distributions statistically different: $\chi^{2}(10)=44.7, p<0.001$.

\subsubsection{Academic Success}

Supporting the findings of research like that of Vegas, Murnane, and Willett [18], this study found that students who believed they were average students were more likely to both consider teaching as a career and believe that being a teacher was the best career option for them. While most respondents viewed themselves as average or above average students (98\%), there was a greater trend for those willing to consider teaching to label themselves average students (see Table 13). Therefore, while $74 \%$ of respondents who would definitely not consider teaching as a career viewed themselves as above average students, only $64 \%$ of students who said they would consider the teaching profession indicated they were above average. Further, while only $45 \%$ of those who felt teaching was the best career option for them indicated they were above average students academically, much larger percentages 
of self-reported above average students $(75 \%)$ indicated they felt there were better career options for them than teaching (see Table 14).

Table 13. Disaggregation of students' belief that they are a good student by their willingness to considering teaching.

\begin{tabular}{|c|c|c|c|}
\hline \multirow[b]{2}{*}{ I Would Consider Teaching as a Career } & \multicolumn{3}{|c|}{ I Am a Good Student } \\
\hline & Below Average & Average & Above Average \\
\hline ( $22 \%$ of all respondents) & $2 \%$ & $34 \%$ & $64 \%$ \\
\hline Maybe $(35 \%)$ & $3 \%$ & $23 \%$ & $74 \%$ \\
\hline Disagree $\quad(43 \%)$ & $2 \%$ & $24 \%$ & $74 \%$ \\
\hline All respondents & $2 \%$ & $26 \%$ & $72 \%$ \\
\hline
\end{tabular}

Note: Response distributions were not statistically different: $\chi^{2}(4)=3.0, p=0.557$.

Table 14. Disaggregation of students' belief that they are a good student by their belief that teaching was their best career option.

\begin{tabular}{|c|c|c|c|}
\hline \multirow[b]{2}{*}{ Teaching Is My Best Career Option } & \multicolumn{3}{|c|}{ I Am a Good Student } \\
\hline & Below Average & Average & Above Average \\
\hline Agreed (4\% of all respondents) & 0 & $55 \%$ & $45 \%$ \\
\hline Maybe $(27 \%)$ & $1 \%$ & $32 \%$ & $67 \%$ \\
\hline Disagree $\quad(69 \%)$ & $3 \%$ & $22 \%$ & $75 \%$ \\
\hline All respondents & $4 \%$ & $27 \%$ & $69 \%$ \\
\hline
\end{tabular}

Note: Response distributions statistically different: $\chi^{2}(6)=9.2, p=0.160$.

From this analysis, we find that those who considered themselves to be high-performing students were more likely to dismiss teaching as a possible career. While these data do not indicate a reason for this trend, a variety of possibilities have been suggested. Many point out that the best teachers are not always the highest academic achievers; non-academic attributes are more important. Others speculate that high-achieving students might make good teachers but considering their potential and interests, many see more attractive opportunities for themselves in other careers [29].

\subsubsection{Gender}

A student's gender was a predictive factor only for the dependent variable of whether the individual would consider teaching. When considering other career options, gender became a non-significant factor. Of those who said they would definitely consider teaching as a career, $80 \%$ were female (see Table 15). In general, this finding supports the fact that most people who consider teaching are female [3] (see Table 16). As one parent put it, "I can't in good conscience encourage any of my three boys to consider teaching as a career [because it is] impossible to support a family on a teacher income. I am particularly sad about my middle son because he has a real gift for working with children and actually really likes the idea of being a math teacher."

Table 15. Disaggregation of students' gender by their willingness to considering teaching.

\begin{tabular}{cccc}
\hline I Would Consider Teaching as a Career & Male & Female \\
\hline Agreed & (22\% of all respondents) & $20 \%$ & $80 \%$ \\
& Maybe (35\%) & $23 \%$ & $76 \%$ \\
Disagree (43\%) & $36 \%$ & $63 \%$ \\
All respondents & $28 \%$ & $71 \%$ \\
\hline
\end{tabular}

Note: Response distributions not statistically different: $\chi^{2}(4)=7.2, p=0.124$. 
Table 16. Disaggregation of students' gender by their belief that teaching was their best career option.

\begin{tabular}{|c|c|c|}
\hline Teaching Is My Best Career Option & Male & Female \\
\hline Agreed ( $4 \%$ of all respondents) & $27 \%$ & $73 \%$ \\
\hline Maybe $(27 \%)$ & $12 \%$ & $83 \%$ \\
\hline Disagree $\quad(69 \%)$ & $33 \%$ & $66 \%$ \\
\hline All respondents & $28 \%$ & $71 \%$ \\
\hline
\end{tabular}

Note. Response distributions not statistically different: $\chi^{2}(4)=7.8, p=0.098$.

\subsubsection{Altruistic Beliefs}

Several studies have suggested that many people choose to teach because they see it as a calling $[17,30]$. These studies tend to survey only practicing teachers, but a high percentage of those in our study had altruistic beliefs about teaching as well: $73 \%$ of students, $87 \%$ of parents, and $89 \%$ of teachers. While this variable was predictive of the dependent variables separately, the results of the multivariate predictive analysis (which considers both dependent variables together) did not confirm altruistic beliefs as highly predictive. Tables 17 and 18 present the results of this variable disaggregated by the dependent variables.

Table 17. Disaggregation of students' altruistic feeling toward teaching by their willingness to considering teaching.

\begin{tabular}{ccccc}
\hline \multirow{2}{*}{ I Would Consider Teaching as a Career } & Disagree & Somewhat Agree & Agree \\
\cline { 2 - 4 } Agreed & $(22 \%$ of all respondents) & $2 \%$ & $8 \%$ & $90 \%$ \\
Maybe (35\%) & $5 \%$ & $15 \%$ & $80 \%$ \\
Disagree (43\%) & $10 \%$ & $32 \%$ & $58 \%$ \\
All respondents & $6 \%$ & $21 \%$ & $73 \%$ \\
\hline
\end{tabular}

Note. Response distributions statistically different: $\chi^{2}(10)=31.4, p<0.001$.

Table 18. Disaggregation of students' altruistic feeling toward teaching by their belief that teaching was their best career option.

\begin{tabular}{cccc}
\hline & \multicolumn{2}{c}{ Teaching Is a Noble Profession } \\
\cline { 2 - 4 } Teaching Is My Best Career Option & Disagree & Somewhat Agree & Agree \\
\hline Agreed $\quad(4 \%$ of all respondents) & $18 \%$ & $9 \%$ & $73 \%$ \\
Maybe (27\%) & $1 \%$ & $8 \%$ & $91 \%$ \\
Disagree (69\%) & $8 \%$ & $26 \%$ & $66 \%$ \\
All respondents & $6 \%$ & $21 \%$ & $73 \%$ \\
\hline
\end{tabular}

Note. Response distributions statistically different: $\chi^{2}(10)=27.8, p<0.002$.

Of those who said that they would consider teaching as a career, $90 \%$ agreed that teaching is a noble profession; however, only $58 \%$ of those who said they would not consider teaching agreed. A similar but slightly diminished difference existed in the pattern of responses for the question of teaching being a student's best career option (see Table 18). We were interested to note that $2 \%$ of respondents who indicated that they would consider teaching also indicated they did not consider teaching a noble profession. Equally surprising was the finding that $18 \%$ of those who felt teaching was their best career option did not see teaching as a noble profession.

\subsection{Analysis of Other Influential Factors Predicting Students' Decisions}

Teacher Salary

Most teacher retention and recruitment studies have indicated that teacher compensation is an important issue [19]. In this sample, very few individuals thought teachers are well paid for what 
they do. While teacher pay showed up as important in predicting whether a student would consider teaching, it was only moderately important for those indicating they thought teaching was their best career option (see Tables 19 and 20). A slightly greater proportion of students willing to consider teaching thought teachers were somewhat well paid compared to those unwilling to consider teaching as a viable career.

Table 19. Disaggregation of students' belief about teacher compensation by their willingness to consider teaching.

\begin{tabular}{ccccc}
\hline & & \multicolumn{3}{c}{ Teacher Are Paid Well } \\
\cline { 3 - 4 } I Would Consider Teaching as a Career & Disagree & Somewhat Agree & Agree \\
\hline Agree & (22\% of all respondents) & $57 \%$ & $39 \%$ & $4 \%$ \\
Maybe (35\%) & $52 \%$ & $45 \%$ & $3 \%$ \\
Disagree (43\%) & $71 \%$ & $27 \%$ & $2 \%$ \\
All respondents & $60 \%$ & $37 \%$ & $3 \%$ \\
\hline
\end{tabular}

Note. Response distributions were not statistically different: $\chi^{2}(10)=12.5, p=0.251$.

Table 20. Disaggregation of students' belief about teacher compensation by their belief that teaching was their best career option.

\begin{tabular}{cccc}
\hline & \multicolumn{3}{c}{ Teacher Are Paid Well } \\
\cline { 2 - 4 } Teaching Is My Best Career Option & Disagree & Somewhat Agree & Agree \\
\hline Agreed $\quad(4 \%$ of all respondents) & $60 \%$ & $40 \%$ & 0 \\
Maybe (27\%) & $45 \%$ & $52 \%$ & $3 \%$ \\
Disagree (69\%) & $67 \%$ & $30 \%$ & $3 \%$ \\
All respondents & $60 \%$ & $37 \%$ & $3 \%$ \\
\hline
\end{tabular}

Note. Response distributions statistically different: $\chi^{2}(10)=11.9, p=0.293$.

\section{Conclusions}

Numerous studies have identified factors that likely affect teacher recruitment. Recognizing that career choice for individuals is personal, based on relevant contextual factors that differ for each person, this study identified factors that appeared for the sample studied to more generally influence and predict an individual's decisions to enter the teaching profession.

Using students' willingness to consider teaching and their belief that teaching was their best career option as dependent variables, we found that students' willingness to consider teaching was not (by itself) a sufficient indicator of their likelihood of actually entering the teaching profession. While $22 \%$ of the students in this study indicated they would consider teaching, only $4 \%$ felt teaching would be their best career option.

The primary factor that individuals seemed to consider when making a career decision was their self-efficacy for teaching: Confidence they would be able to teach well. They also found it important to be encouraged by family and others to consider teaching. Two other factors-perception of their prior academic success and belief that teachers were supported by people they knew-also tended to be important. While factors like gender and salary likely were a consideration, they did not seem to have as much predictive influence as the other factors.

One concern suggested by the data is that students do not seem to fully consider work conditions when choosing whether they want a career in teaching. Only one-third of students felt that work conditions for teachers were good, and just 39\% felt that expectations placed on teachers were reasonable. In addition, few students $(9 \%)$ considered their fellow students well behaved in class. These factors did not seem to feature prominently in a student's decision to teach; however, these factors tend to be quite influential in predicting a teacher's thoughts of leaving the profession [31].

High school students consider many factors when making career decisions. While increasing teacher pay is often suggested as a potential solution to problems of both teacher recruiting and teacher 
retention, analysis from this study suggests that increasing teacher pay by itself will likely not solve the problem. Additional systemic issues must be addressed if a more complete and permanent solution is to be found. For recruitment, these include the need to encourage students with a propensity for teaching to teach, helping them recognize their abilities, and encouraging them to follow that career path.

As encouragement is an essential component in teacher recruitment, future research on this factor is warranted. Students' tendency to downplay difficulties in teachers' job situations should also be given further consideration. Comprehensive studies on both the supply and demand of teachers could lead to long-term solutions to mitigate teacher shortages.

Author Contributions: Conceptualization, S.S.C., R.S.D., S.P.H., and B.B.; data curation, R.S.D.; formal analysis, S.S.C. and R.S.D.; investigation, S.S.C., R.S.D., and J.H.; methodology, R.S.D., S.P.H., J.H., and B.B.; project administration, R.S.D.; supervision, B.B.; writing—original draft, S.S.C.; writing—review and editing, S.S.C., R.S.D., S.P.H., and J.H.

Funding: This research received no external funding.

Conflicts of Interest: The authors declare no conflict of interest.

\section{References}

1. Grissmer, D.W.; Kirby, S.N. Teacher Attrition: The Uphill Climb to Staff the Nation's Schools; Rand, Center for the Study of the Teaching Profession: Santa Monica, CA, USA, 1987.

2. Gray, L.; Taie, S. Public School Teacher Attrition and Mobility in the First Five Years: Results from the First Through Fifth Waves of the 2007-08 Beginning Teacher Longitudinal Study. First Look. NCES 2015-337; National Center for Education Statistics, 2015. Available online: https://nces.ed.gov/pubs2015/2015337.pdf (accessed on 11 November 2019).

3. Ingersoll, R.; Merrill, L.; Stuckey, D. Seven Trends: The Transformation of the Teaching Force; CPRE Research Report \# RR-80; Consortium for Policy Research in Education: Philadelphia, PA, USA, 2014. [CrossRef]

4. Rinke, C.R. Why Half of Teachers Leave the Classroom: Understanding Recruitment and Retention in Today's Schools; Rowman \& Littlefield Education: Blue Ridge Summit, PA, USA, 2014.

5. Glazer, J. Learning from those who no longer teach: Viewing teacher attrition through a resistance lens. Teach. Teach. Educ. 2018, 74, 62-71. [CrossRef]

6. Sutcher, L.; Darling-Hammond, L.; Carver-Thomas, D. A Coming Crisis in Teaching? Teacher Supply, Demand, and Shortages in the US. Learning Policy Institute, 2016. Available online: https://learningpolicyinstitute.org/ product/coming-crisis-teaching (accessed on 11 November 2019).

7. Colby, S.L.; Ortman, J.M. Projections of the Size and Composition of the US Population: 2014 to 2060: Population Estimates and Projections. 2017. Available online: https:/census.gov/content/dam/Census/ library/publications/2015/demo/p25-1143.pdf (accessed on 11 November 2019).

8. Hussar, W.J.; Bailey, T.M. Projections of Education Statistics to 2025. NCES 2017-019; National Center for Education Statistics, 2017. Available online: https://nces.ed.gov/pubs2017/2017019.pdf (accessed on 11 November 2019).

9. Ravitch, D. The Death and Life of the Great American School System: How Testing and Choice are Undermining Education; Basic Books: New York, NY, USA, 2016.

10. Aragon, S. Teacher Shortages: What We Know. Teacher Shortage Series. Education Commission of the States, 2016. Available online: https://www.ecs.org/wp-content/uploads/Teacher-Shortages-What-We-Know.pdf (accessed on 11 November 2019).

11. U.S. Department of Education, Office of Postsecondary Education, Enrollment in Teacher Preparation Programs. 2015; pp. 5-6. Available online: https://title2.ed.gov/Public/44077_Title_II_Issue_Brief_ Enrollment_V4a.pdf (accessed on 11 November 2019).

12. Lindquist, P.; Nordänger, U.K. Already elsewhere-A study of (skilled) teachers' choice to leave teaching. Teach. Teach. Educ. 2016, 54, 88-97. [CrossRef]

13. Flores, M.A.; Niklasson, L. Why do student teachers enroll for a teaching degree? A study of teacher recruitment in Portugal and Sweden. J. Educ. Teach. 2014, 40, 328-343. [CrossRef] 
14. Wigfield, A.; Eccles, J.S. Expectancy-value theory of achievement motivation. Contemp. Educ. Psychol. 2000, 25, 68-81. [CrossRef] [PubMed]

15. Lent, R.W.; Brown, S.D.; Hackett, G. Social cognitive career theory. Career Choice Dev. 2002, 4, $255-311$.

16. Arnup, J.; Bowles, T. Should I stay or should I go? Resilience as a protective factor for teachers' intention to leave the teaching profession. Aust. J. Educ. 2016, 60, 229-244. [CrossRef]

17. Bennett, S.V.; Brown, J.J.; Kirby-Smith, A.; Severson, B. Influences of the heart: Novice and experienced teachers remaining in the field. Teach. Dev. 2013, 17, 562-576. [CrossRef]

18. Vegas, E.; Murnane, R.J.; Willett, J.B. From high school to teaching: Many steps, who makes it? Teach. Coll. Rec. 2001, 103, 427-449. [CrossRef]

19. Han, S.W.; Borgonovi, F.; Guerriero, S. What motivates high school students to want to be teachers? The role of salary, working conditions, and societal evaluations about occupations in a comparative perspective. Am. Educ. Res. J. 2018, 55, 3-39. [CrossRef]

20. Azman, N. Choosing teaching as a career: Perspectives of male and female Malaysian student teachers in training. Eur. J. Teach. Educ. 2012, 36, 113-130. [CrossRef]

21. Fray, L.; Gore, J. Why people choose teaching: A scoping review of empirical studies, 2007-2016. Teach. Teach. Educ. 2018, 75, 153-163. [CrossRef]

22. Chong, S.; Low, E.-L. Why I want to teach and how I feel about teaching-Formation of teacher identity from pre-service to the beginning teacher phase. Educ. Res. Policy Pract. 2009, 8, 59-72. [CrossRef]

23. Ralph, A.M.; MacPhail, A. Pre-service teachers' entry onto a physical education teacher education programme, and associated interests and dispositions. Eur. Phys. Educ. Rev. 2015, 21, 51-65. [CrossRef]

24. Lamb, J.; Puskar, K.; Tusaie-Mumford, K. Adolescent research recruitment issues and strategies: Application in a rural school setting. J. Pediatr. Nurs. 2001, 16, 43-52. [CrossRef] [PubMed]

25. Pincus, D.; Friedman, A. Improving children's coping with everyday stress: Transporting treatment interventions to the school setting. Clin. Child Fam. Psychol. Rev. 2004, 7, 223-240. [CrossRef] [PubMed]

26. Harrell, J.; Bradley, C.; Dennis, J.; Frauman, A.; Criswell, E. School-based research: Problems of access and consent. J. Pediatr. Nurs. 2000, 15, 14-21. [CrossRef] [PubMed]

27. Krejecie, R.V.; Morgan, D.W. Determining sample size for research activities. Educ. Psychol. Meas. 1970, 30, 608. [CrossRef]

28. Creswell, J.W. Educational Research: Planning, Conducting, and Evaluating Quantitative and Qualitative Research, 3rd ed.; Pearson Education: Upper Saddle River, NJ, USA, 2008.

29. Goldhaber, D.; Gross, B.; Player, D. Teacher career paths, teacher quality, and persistence in the classroom: Are public schools keeping their best? J. Policy Anal. Manag. 2011, 30, 57-87. [CrossRef]

30. Tang, S.Y.; Wong, P.M.; Wong, A.K.; Cheng, M.M. What attracts young people to become teachers? A comparative study of pre-service student teachers' motivation to become teachers in Hong Kong and Macau. Asia Pac. Educ. Rev. 2018, 19, 433-444. [CrossRef]

31. Hanks, J.; Davies, R.; Christensen, S.; Harris, S.; Bowles, B. Teacher Attrition: A Predictive Analysis of Why Teachers Consider Leaving the Profession. (Manuscript in Review).

(C) 2019 by the authors. Licensee MDPI, Basel, Switzerland. This article is an open access article distributed under the terms and conditions of the Creative Commons Attribution (CC BY) license (http://creativecommons.org/licenses/by/4.0/). 